\title{
Use of a distributed catchment model to assess hydrologic modifications in the Upper Ganges Basin
}

\author{
L. Bharati ${ }^{1}$, V. Smakhtin ${ }^{2}$, P. Jayakody ${ }^{2}$, N. Kaushal ${ }^{3} \&$ P. Gurung ${ }^{1}$ \\ ${ }^{1}$ International Water Management Institute (IWMI), Lalitpur, Nepal \\ ${ }^{2} I W M I-H Q$, Colombo, Sri Lanka \\ ${ }^{3}$ WWF-India, New-Delhi, India
}

\begin{abstract}
Allocation of river water to cities, industries and agriculture has been a common practice in river basin planning and management. It is now widely accepted that water also needs to be allocated for aquatic environments - alongside the demands of other users. Discharge data are a pre-requisite for calculating such environmental demands - Environmental Flows (EF) - regardless of the EF assessment method used. This paper describes the application of a distributed hydrological model (SWAT) to simulate discharges, which were then used for EF assessment in the Upper Ganges River in India (total area: $87000 \mathrm{~km}^{2}$ ). The EF assessment was done using a multidisciplinary, multi-stakeholder approach (Building Blocks methodology). The EF method involved several stakeholder workshops with various expert groups and extensive field studies. This is the first time that a comprehensive EF assessment has been done in India. The characteristic feature of the study is that cultural and religious water demands were also incorporated into the assessment of $\mathrm{EF}$ requirements as the conservation of the river's spiritual traits were recognized by the stakeholders as being as important as the maintenance of its ecological integrity. The assessment resulted in EF requirements ranging from $72 \%$ of Mean Annual Runoff (MAR) in the upper stretches to $45 \%$ of (MAR) in the lower stretches, which is coherent with the ecological and spiritual status of the reaches.
\end{abstract}

Keywords: Ganges Basin, hydrological modeling, environmental flows assessment. 


\section{Introduction}

Hydrological modifications typically refer to man-made changes in surface water flow. These changes mainly affect the quantity of water delivered through a system i.e. the river's flow regime, which in turn, affects water quality as well as riverine ecosystems. As the flow regime is recognized as a key factor in determining biological and physical processes and characteristics in rivers any river restoration program or environmental flows (EF) assessment needs to consider natural flows i.e. the concerned river without significant hydrologic modifications. In river basins, especially in the developing world, where river discharge measurements have not been done for a long time, measured flows under natural conditions may not exist. In some cases however, as in the Ganges river system in India, discharge data for some gauging stations exist but are not accessible to the public due to national security laws. Therefore, in this study, a catchment scale distributed hydrological model was used (Soil-Water Assessment Tool-SWAT) to simulate water balances and generate flows without any infrastructure projects (Dams, Barrages and Reservoirs) in the Upper Ganges Basin in India. The purpose of this exercise was to 1) Understand the Upper Ganges basin in present and more "natural" conditions and 2) to generate "naturalized" flows for the purpose of calculating EF requirements in three sites along the main channel (Figure 1).

\subsection{Background: The Upper Ganges basin}

The Ganges River Basin covers $981,371 \mathrm{~km}^{2}$ shared by India, Nepal, China (Tibet) and Bangladesh. The River originates in Uttar Pradesh, India from the Gangrotri glacier, and has many tributaries including the Mahakali, Gandak, Kosi and Karnali which originate in Nepal and Tibet. The focus of the present study is on the Upper Ganges - the upper main branch of the River. Therefore, for this study, the Upper Ganges Basin (UGB) was delineated by using the $90 \mathrm{~m}$ SRTM digital elevation map with Kanpur barrage as the outlet point (Figure 1). The total area of the UGB is $87,790 \mathrm{~km}^{2}$. The elevation in the UGB ranges from $7500 \mathrm{~m}$ at upper mountain region to $100 \mathrm{~m}$ in the lower plains. Annual average rainfall in the UGB is in the range of $550-2500 \mathrm{~mm}$. A major part of the rains is due to the south-western monsoon from July to October.

The main river channel is highly regulated with dams, barrages and corresponding canal systems (Figure 1). The two main dams are Tehri and Ramganga. There are three main canal systems. The Upper Ganga Canal takes off from the right flank of the Bhimgoda barrage with a head discharge of 190 $\mathrm{m}^{3} / \mathrm{s}$, and presently, the gross command area is about 2 million ha. The Madhya Ganga canal provides annual irrigation to 178,000 ha. Similarly, the Lower Ganga canal comprises a weir across the Ganga at Narora and irrigates 0.5 million ha. 


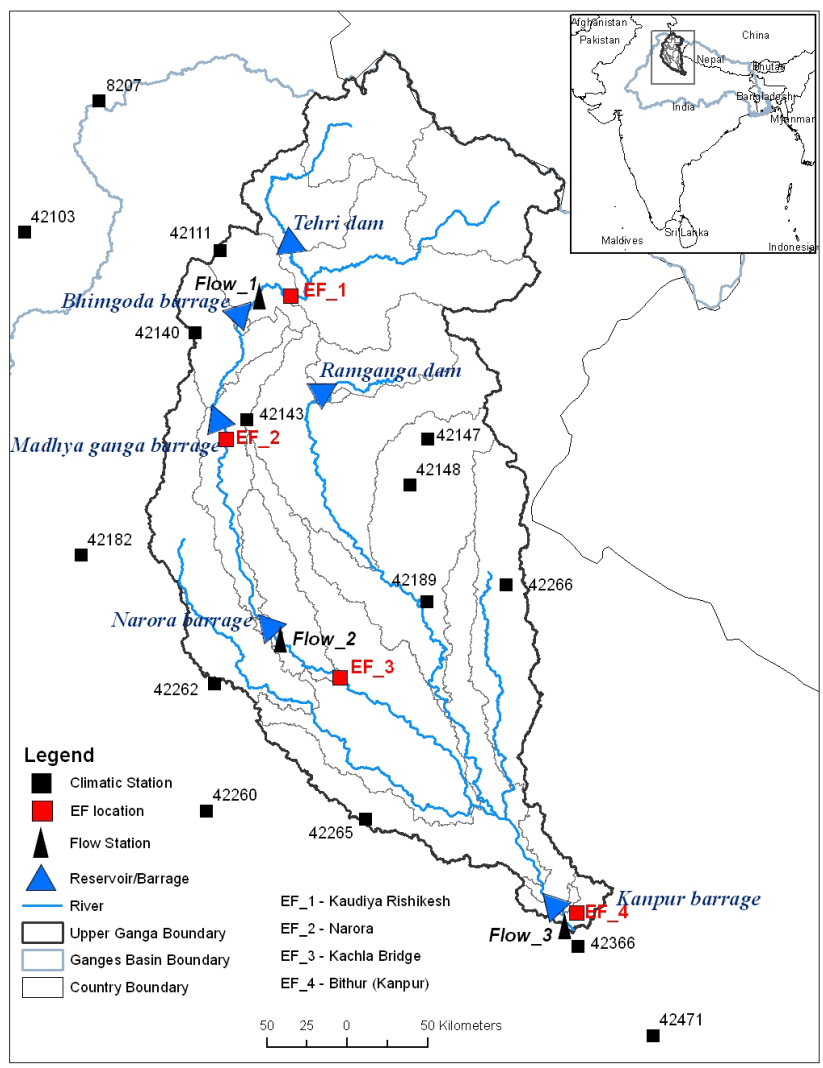

Figure 1: A map of the Upper Ganges River catchment showing the boundaries of the UGB, location of the barrages, reservoirs, EF sites and observed data points used in the study.

\section{Hydrological modeling}

The Soil Water Assessment Tool (SWAT) is a process-based continuous hydrological model that predicts the impact of land management practices on water, sediment and agricultural chemical yields in complex basins with varying soils, land use and management conditions [1-3, 5]. SWAT requires three basic spatial input files: Digital Elevation Model (DEM), Soil map and Land Use/Land Cover (LULC) map. For this study, the DEM was obtained from the 90m Shuttle Radar Topography Mission (SRTM) data, for soils, the FAO soil map was used and the LandSat TM was used for the landuse/cover map. SWAT also requires time series of observed climate data i.e. rainfall, minimum and maximum temperature, sunshine duration, wind speed and relative humidity. In this study data from 15 climate stations were used. The location of the climate stations can be seen in Figure 1. Data from the climate stations are spatially interpolated by the model to produce a gridded map of climate input. In order to validate the 
model, flow data from three barrages were used (Figure 1). Due to the restrictions on Ganges data from the Indian Central Water Commission (CWC), only a very short time series of data from these barrages were available. The observed flow data except for one site (Narora) are monthly time series, while the model works with daily time step. Simulated daily flow values therefore, had to be accumulated into monthly for comparison. This created some uncertainty. Also, the quality of the observed data could not be ascertained. Therefore the model was set up and calibrated in the conditions of extreme lack of reliable observations. The existing dams, barrages and irrigation deliveries were incorporated in the model using available salient features from the relevant barrage/dam authorities.

\subsection{SWAT model calibration and validation}

The period from 2000 to 2005 was used for model calibration and validation, but continuous data for these years were not available from all three available stations. Therefore, the available data between 2000 and 2005 from each station were divided into two sets. The first set was used for model calibration and the second - for validation. Model parameters were calibrated simultaneously for the all three flow stations.

The model performance was determined by calculating coefficient of determination $\left(\mathrm{R}^{2}\right)$ and the Nash-Sutcliffe Efficiency (NSE). The calculated $\mathrm{R}^{2}$ and NSE in each simulation are presented in the Table 1 . The model performance for both the calibration and validation period was within an acceptable range according to model performance ratings found in the cited study [4]. Figure 2 shows observed and simulated discharges from Narora barrage. The comparison between measured and simulated hydrographs is also acceptable.

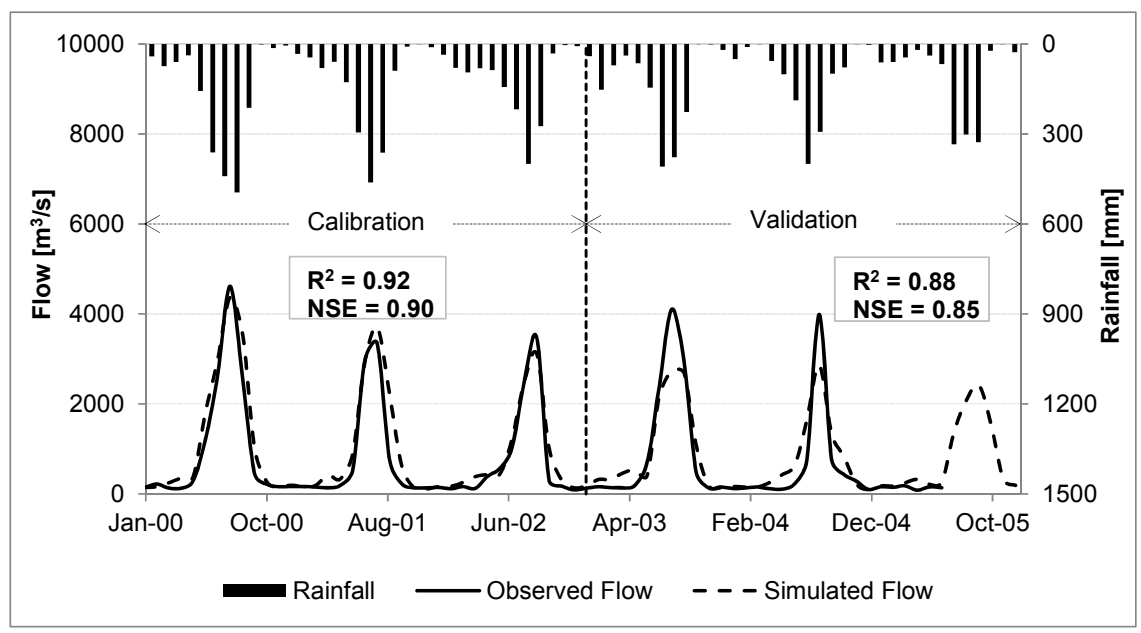

Figure 2: Observed and simulated flows at the Narora barrage. 
Table 1: $\quad$ Model performance statistics.

\begin{tabular}{|c|c|c|c|c|c|}
\hline \multirow{2}{*}{$\begin{array}{l}\text { Station } \\
\text { code }\end{array}$} & \multirow{2}{*}{$\begin{array}{c}\text { Model } \\
\text { Efficiencies }\end{array}$} & \multicolumn{2}{|c|}{ Calibration Period } & \multicolumn{2}{|c|}{ Validation Period } \\
\hline & & Statistic & $\begin{array}{c}\text { Performance } \\
\text { Ratings }\end{array}$ & Statistic & $\begin{array}{c}\text { Performance } \\
\text { Ratings }\end{array}$ \\
\hline \multirow[t]{4}{*}{ Flow_1 } & R2 & 0.86 & $(>0.85)$ & 0.84 & $(0.65-0.85)$ \\
\hline & & & Excellent & & Very Good \\
\hline & NSE & 0.67 & $(0.65-0.85)$ & 0.81 & $(0.65-0.85)$ \\
\hline & & & Very Good & & Very Good \\
\hline \multirow[t]{4}{*}{ Flow_2 } & R2 & 0.92 & $(>0.85)$ & 0.88 & $(>0.85)$ \\
\hline & & & Excellent & & Excellent \\
\hline & NSE & 0.90 & $(>0.85)$ & 0.85 & $(0.65-0.85)$ \\
\hline & & & Excellent & & Very Good \\
\hline \multirow[t]{4}{*}{ Flow_3 } & R2 & 0.86 & $(>0.85)$ & 0.60 & $(0.60-0.64)$ \\
\hline & & & Excellent & & Good \\
\hline & NSE & 0.82 & $(0.65-0.85)$ & 0.66 & $(0.65-0.85)$ \\
\hline & & & Very Good & & Very Good \\
\hline
\end{tabular}

\subsection{Water balance results of model simulation}

Figure 3 shows the mean monthly water balance for the basin. In the water balance plots, four hydrological components are considered i.e. rainfall (RF), actual evapotranspiration (ET), net water yield (NWY) which is routed runoff from the sub-basin and balance closure. The term 'balance closure' comprises of groundwater recharge, change in soil moisture storage in the vadoze zone and model inaccuracies. The mean monthly results from 1971 to 2005 show that there are large temporal variations in the water balance parameters. Most of the rainfall in the basin falls during the monsoon months of June-Sept. The maximum rainfall of $338 \mathrm{~mm}$ occurred during August and a minimum of $7 \mathrm{~mm}$ in November. Similarly, water yields are also much higher during the monsoon months as compared to the dry season. ET however, which is more related to land cover was found to be lowest during the winter months i.e. Nov- Jan. (post rice harvest).

Annual average rainfall, actual evapotranspiration and net water yield of the whole basin were $1184 \mathrm{~mm}, 415 \mathrm{~mm}$ and $615 \mathrm{~mm}$ respectively however, there was large variation in spatial distribution. Rainfall, ET and water yield were found to be higher in the forested and mountainous upper catchment areas. In the upper catchment sub-basins, water yield is higher than ET however; in the agriculture dominated some lower sub-basins, ET values were higher than water yield. 


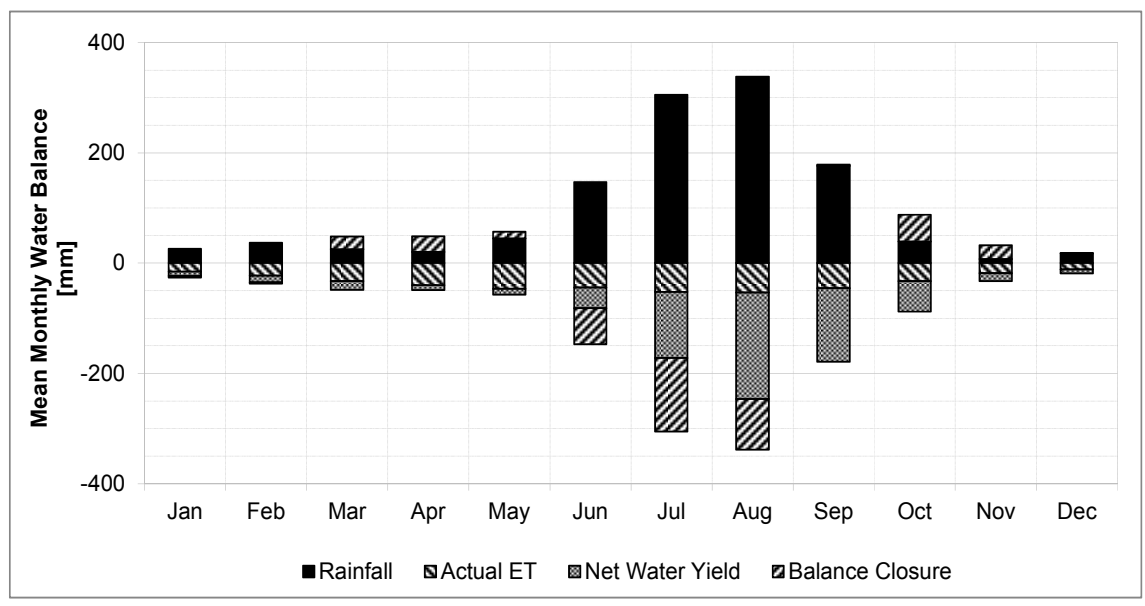

Figure 3: $\quad$ Mean monthly water balance results of model simulation (19712005).

\subsection{Simulation of natural flow conditions for the four EF sites}

Scenarios for natural flow conditions represent minimal human intervention in the basin i.e. without dams and irrigation infrastructure. Due to lack of real measured flow data under such conditions, in this study, the calibrated model for present conditions from 1971-2005 were run by removing all water infrastructure from the model set up. In addition, land use was also varied between the present day and natural conditions. Irrigated crops such as rice, wheat, corn, bajra, sugarcane, potato represent the major crops types during present conditions. Natural conditions' scenario was characterized by rain-fed crops such as mung bean and wheat, as well as a larger area covered in natural forest. Parameters in the model were changed accordingly to reflect the difference between scenarios in the model. The names and locations of the EF sites for which natural flows have been simulated are shown in Figure 1. The selected EF sites are representative of the different agro-ecological zones in the study river stretch.

Simulated daily flow data for the most downstream site (EF 4) are summed up at monthly and annual time steps and are presented below. Table 2 contains the details of some typical flow sequences at the EF sites for each calendar month including the range of base flows, magnitude, number and duration of floods. This information was obtained from visual inspection of the simulated time series for each EF site. Base flow i.e. the ground water that contributed to stream flow has been estimated from modeled stream flows by using the automated SWAT base flow filter (Arnold et al., 1995). When the number of floods in the table is specified as $<<1$ it implies that in 35 years of record only a few (less 
than 10) events have been identified in this month. In cases when this value is " $<$ 1 ", the floods in this month occur more frequently, but their total count is less than 30 (e.g. 20-30) in 35 years. If the number of floods is specified as " 0 ", it implies that none or only a few insignificant events in this month were simulated. In monsoonal months it is difficult to separate events from each other and the approach was - to rather identify these events over the entire wet period. Such cases are at two downstream sites (Table 2). In such case, the range of event numbers is given, which is normally $1-2$, implying that there is 1 or 2 large events often spanning through the wet months.
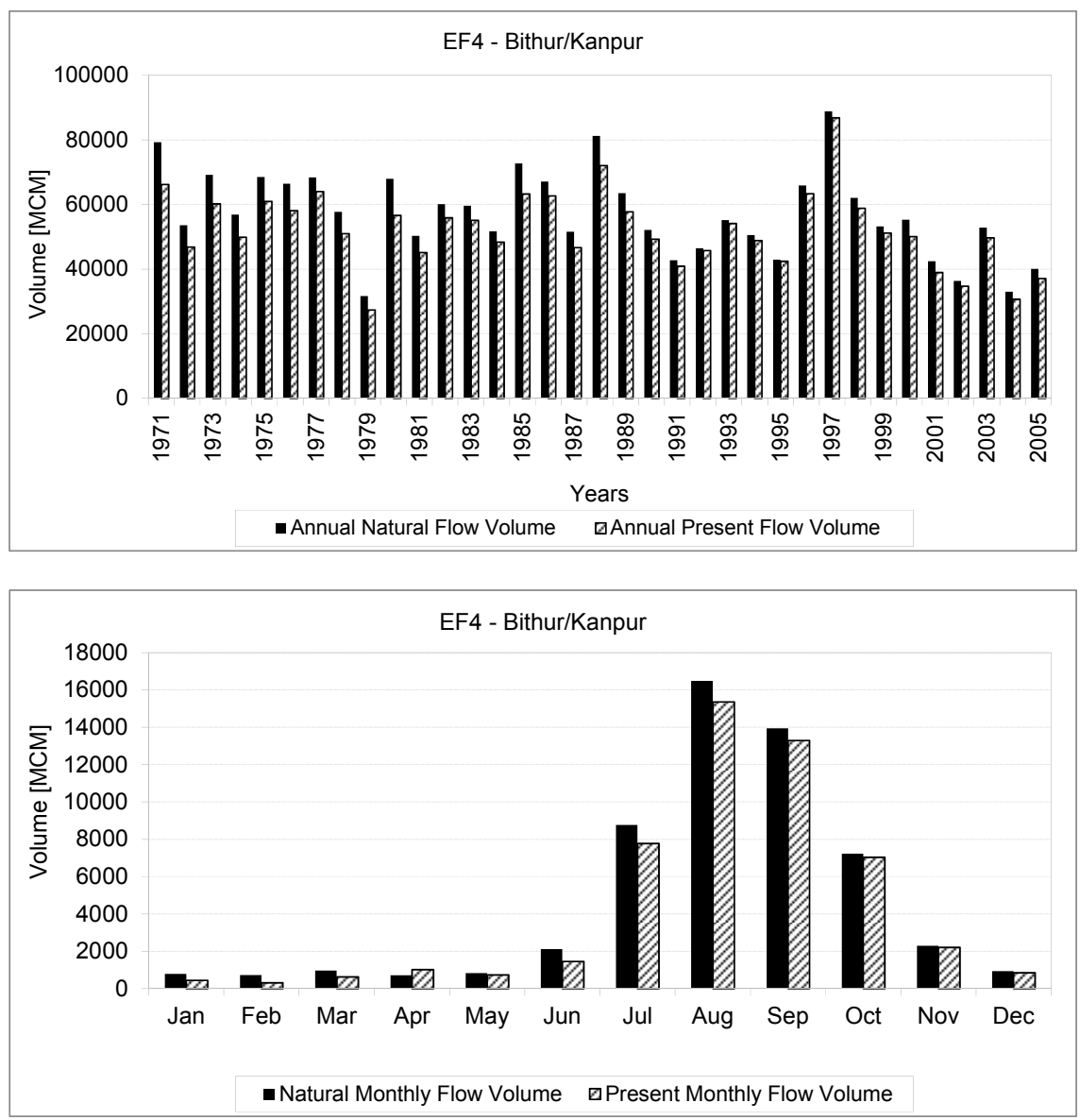

Figure 4: Annual flow totals (top) and average monthly flow distribution (bottom) for Bithur/Kanpur. 


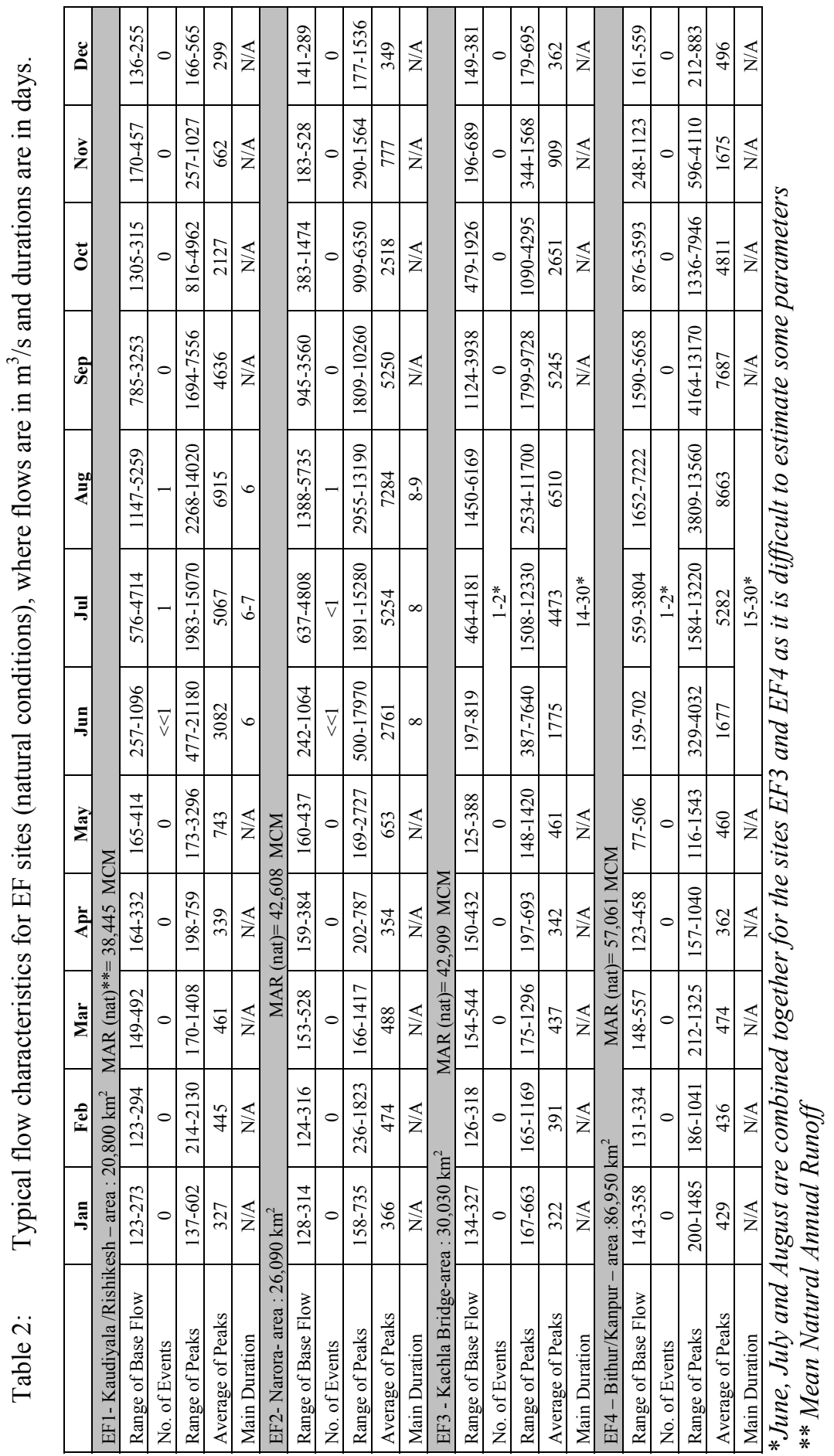




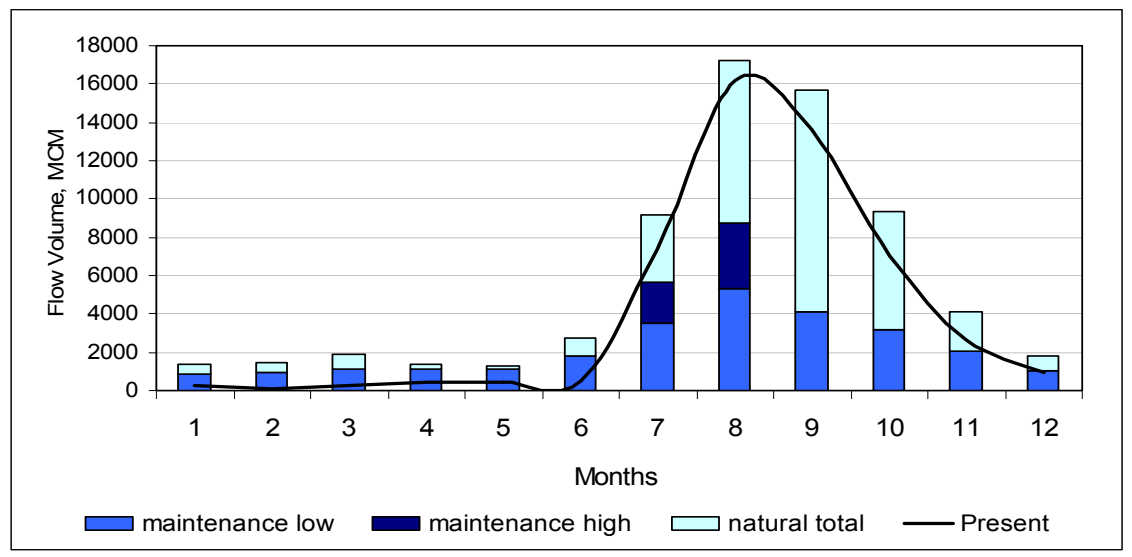

Figure 5: Monthly E-flows requirement for the most downstream site EF 4 (Kanpur) for low flow and high flows maintenance. The present and natural flows are also shown.

\section{Environmental flows (EF) assessments}

For this study, the Building Block Methodology (BBM) was selected for the assessment of E-Flows. This methodology allows the user to integrate local requirements, for instance - in case of River Ganga, the spiritual and cultural aspects are of immense importance and thus require due consideration. In addition to the spiritual and cultural aspects, the following sub-components were identified: Fluvial Geomorphology, Biodiversity, Livelihoods and Water Quality. Experts (1 to 3) were then identified for each of the above mentioned areas and were asked to spend one year collecting necessary data and information. In the final flow setting workshop, the expert group members collectively determined the final EF requirements. The naturalized flows as well as the flow characteristics presented in Table 3 were used as a starting point for setting E-flows requirements. The assessment resulted in EF requirements ranging from $72 \%$ of Mean Annual Runoff (MAR) in the upper stretches to $45 \%$ of (MAR) in the lower stretches. Figure 5 shows the monthly E-flows requirement for the most downstream site (Kanpur). The figure presents the monthly E-Flows requirement for both the low-flow as well as high flow maintenance. The figure also presents the naturalized flows as well as simulated present day flows. The E-Flows requirements were calculated as $45 \%$ of mean annual runoff (MAR). The present day flows are lower than the E-Flows requirements for all twelve months.

\section{Conclusions}

This study is the first time that a comprehensive method (BBM) has been used for E-flows assessment in the Ganges river. Therefore, the exercise was of great 
interest to local environmentalists, scientists as well as the relevant government agencies. The project was coordinated by WWF-India. The final report is in preparation and an E-flows assessment manual for India is also being planned. Furthermore, The EF estimates are now being considered in the modeling of basin development scenarios under conditions of current climate and projected climate changes.

One of the main constraints in this study was due to the restrictions on accessibility of past flow data as well as the unavailability of natural flow data from the Ganges river. Due to this constraint, in this project, SWAT was used to simulate current as well as naturalized flows. This data was then used as a basis to determine E-flows requirements according to the BBM method. Although the model was validated with several years of measured data, the accuracy of the simulations would have increased with the availability of long time series of flow data as well as climate data. The discussion to make flow data available for the Ganges has been going on for quite some time however, until this becomes a reality; this limitation will continue to affect all future studies.

\section{References}

[1] Arnold, J.G., Srinivasan, P., Muttiah, R.S., Williams, J.R. Large area hydrologic modeling and assessment. Part I. Model development. J. Am. Water Resour. Assoc. 34, pp. 73-89, 1998.

[2] Arnold, J.G., Allen, P.M., Muttiah, R., Bernhardt, G. Automated Base Flow Separation and Recession Analysis Techniques. GROUND WATER, Vol. 33, No. 6, pp, 1010 - 1018, 1995.

[3] Green, C.H., Griensven, A.V. Autocalibration in hydrologic modeling: Using SWAT2005 in small-scale watersheds. Environmental Modelling \& Software. Elsevier Science, Vol. 23, Issue 4, pp. 422 - 434, 2008

[4] Liu, Y.B. and Smedt, F. D. WetSpa Extension, Documentation and User Manual. Department of Hydrology and Hydraulic Engineering, Vrije Universiteit Brussel, 2004.

[5] Srinivasan, R., Ramanarayanan, T.S., Arnold, J.G. and Bednarz, S.T. Large area hydrological modeling and assessment. Part II: Model application. J. Am. Water Resources Ass., 34(1), pp. 91-101, 1998. 